PENDIDIKAN

Publish by: Library of STKIP PGRI Sumatera Barat

E-ISSN : 2775-5770

Vol. 1 No. 4 (November 2021) (748-756)

http://ejournal.stkip-pgri-sumbar.ac.id/index.php/horizon

\title{
PENGARUH DISIPLIN, MOTIVASI BELAJAR, KETERAMPILAN \\ MENGAJAR GURU, MEDIA PEMBELAJARAN TERHADAP MINAT \\ BELAJAR SISWA KELAS XII AKL SMK NEGERI 2 BUKITTINGGI PADA PEMBELAJARAN JARAK JAUH DI ERA NEW NORMAL
}

\author{
Illya Fira, Ansofino, Nora Susanti \\ Program Studi Pendidikan Akuntansi STKIP PGRI Sumatera Barat \\ illyafira99@gmail.com
}

Submitted: 20-10-2021, Reviewed: 03-11-2021, Accepted: 09-11-2021

\begin{abstract}
This study aims to analyze: 1.) The effect of learning discipline on interest in learning 2.) The effect of learning motivation on interest in learning 3.) The effect of teacher teaching skills on interest in learning 4.) The effect of learning media on interest in learning 5.) To analyze learning discipline, learning motivation, teacher teaching skills and learning media simultaneously on online learning outcomes in economics class XII AKL SMK Negeri 2 Bukittinggi. The population of this study were students of class XII AKL SMK Negeri 2 Bukittinggi, amounting to 90 people. The sampling technique used was Stratified Sampling with a total sample of 62 people. The instrument used for this research is a closed questionnaire using the Multilevel Linear Regression test and hypothesis testing with $t$ test and $F$ test. The results of the study show that: (1) learning discipline greatly affects students' interest in learning, a greater influence is found in the sample group of non-current internet network ownership, this is because if internet access is inadequate it will affect students' interest in learning; (2) learning motivation greatly affects students' interest in learning, the biggest influence comes from students with poor internet access this is due to the lack of student motivation in distance learning because the network is less stable this affects interest in learning; (3) teacher's teaching skills greatly affect interest in learning, the greater influence comes from samples with ownership of internet access that is not smooth, this is because if internet access is lacking, the learning process changes from conventional to network that still does not master technology so that the learning process does not run. maximum ; (4) learning media greatly influences interest in learning, the biggest influence comes from samples of internet access that are not smooth, this is because not all students have internet access and difficulties in using the learning media provided, so that it will affect students' interest in learning.
\end{abstract}

Keywords: Discipline, Learning Motivation, Teacher Teaching Skills, Learning Media, Learning Interest.

PENDAHULUAN

Secara bahasa, minat berarti kecenderungan hati yang tinggi terhadap sesuatu (Depdikbud, 2008:1027) Menurut Syahputra (2020) minat belajar adalah keadaan 


\section{HORIZON}

PENDIDIKAN
JURNAL HORIZON PENDIDIKAN

Publish by: Library of STKIP PGRI Sumatera Barat

E-ISSN : 2775-5770

Vol. 1 No. 4 (November 2021) (748-756)

http://ejournal.stkip-pgri-sumbar.ac.id/index.php/horizon

psikologis dimana seseorang menunjukkan gejala seperti hasrat, gairah, dan emosi yang mempengaruhi proses modifikasi perilaku melalui berbagai aktivitas, seperti tuntutan akan pengetahuan dan pengalaman. Minat pada dasarnya besarnya penerimaan diri dengan sesuatu diluar diri. Semakin kuat atau dekat hubungan tersebut, semakin besar minatnya. Dari pengertian di atas dapat disimpulkan bahwa minat adalah keadaan dimana seseorang merasa suka dan tertarik pada suatu hal atau aktivitas, dimana keadaan ini menjadi penggerak dalam melakukan aktivitas yang disukainya. Minat membuat seseorang merasa senang dan gembira dalam menjalankan aktivitas. Tanpa adanya minat, seseorang tidak bisa melakukan sesuatu atau merasa tertekan dalam menjalankan aktivitas yang tidak diinginkannya.

Minat belajar dapat diukur melalui 4 indikator sebagaimana yang disebutkan oleh Safari dalam (Syahputra, 2020) seseorang yang memiliki minat belajar akan menunjukkan perasaan senang, ketertarikan, perhatian, dan keterlibatan selama mengalami proses belajar.

\section{Menurut Djaali (2007:121).} menyatakan bahwa minat dapat diekspresikan melalui pernyataan yang menunjukkan bahwa siswa lebih menyukai suatu hal dari pada hal lainnya, dapat pula dimanifestasikan melalui partisipasi dalam suatu aktivitas. Sedangkan menurut Arikunto (2010:21) minat merupakan faktor internal yang dapat mempengaruhi prestasi belajar siswa disamping dipengaruhi oleh faktor lain. Dapat disimpulkan bahwa minat merupakan keinginan yang besar terhadap sesuatu.

Minat atau kesenangan belajar siswa adalah suatu syarat psikologi pada diri siswa yang dapat mempengaruhi siswa dalam belajar. Minat bisa muncul lantaran daya tarik dari luar dan juga datang berdasarkan hati sanubari. Minat yang besar terhadap sesuatu adalah modal yang besar artinya untuk mencapai atau memperoleh benda atau tujuan yang diminati. Timbulnya minat belajar ditimbulkan berbagai hal, diantaranya lantaran 
HORIZON

PENDIDIKAN

JURNAL HORIZON PENDIDIKAN

Publish by: Library of STKIP PGRI Sumatera Barat

E-ISSN : 2775-5770

Vol. 1 No. 4 (November 2021) (748-756)

http://ejournal.stkip-pgri-sumbar.ac.id/index.php/horizon

keinginan yang bertenaga untuk mempertinggi prestise atau memperoleh pekerjaan yang baik dan ingin hidup bahagia. Minat belajar yang besar cenderung menghasilkan prestasi belajar yang tinggi, kebalikannya minat belajar kurang akan membentuk prestasi yang rendah (Dalyono, 2005:57).

Berdasarkan pendahuluan tersebut masalah dalam penelitian ini adalah :

1. Sebanyak $22 \%$ dari siswa tidak memiliki smartphone atau hanya menumpang milik keluarganya sehingga kesulitan dalam proses pembelajaran jarak jauh (PJJ).

2. Proses Pembelajaran Jarak Jauh (PJJ) yang masih baru dalam dunia pendidikan Indonesia mengakibatkan berkurangnya partisipasi dan perhatian peserta didik dibandingkan dengan pembelajaran konvensional.

3. Metode Mengajar Guru pada masa Pandemi Covid-19 secara daring menggunakan media penunjang pendidikan seperti Zoom, Google Class, Sicadiak Pandai, Whatsapp Group, dan ELearning sekolah. Sehingga mengharuskan siswa untuk mempunyai smartphone atau telpon Android untuk menunjang kegiatan pembelajaran jarak jauh (PJJ).

4. Ketetapan waktu dalam pengumpulan tugas siswa, terdapat banyak siswa yang masih terlambat dalam mengumpulkan tugas. Dimana kemauan siswa untuk mengerjakan tugas yang masih rendah, sehingga nilai yang diperoleh kurang optimal.

5. Dibandingkan dengan pembelajaran konvensional/luar jaringan tingkat partisipasi dan perhatian siswa menurun dalam pembelajaran jarak jauh

6. Media pembelajaran yang digunakan oleh guru masih terbatas mengingat situasi dan kondisi siswa, sehingga pembelajaran daring belum optimal

7. Pekerjaan orang tua siswa yang beragam dari PNS hingga wiraswasta mengharuskan orang tua siswa lebih banyak menghabiskan waktu untuk bekerja daripada dirumah. Dalam keadaan ini membuat orang tua 


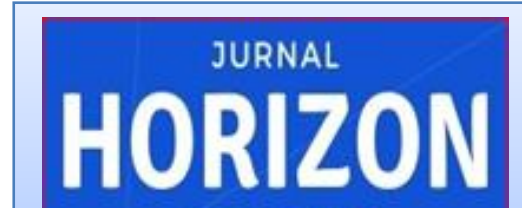

PENDIDIKAN
JURNAL HORIZON PENDIDIKAN

Publish by: Library of STKIP PGRI Sumatera Barat

E-ISSN : 2775-5770

Vol. 1 No. 4 (November 2021) (748-756)

http://ejournal.stkip-pgri-sumbar.ac.id/index.php/horizon kurang

memperhatikan

perkembangan anaknya, apakah anaknya sudah mandiri atau belum dalam hal belajar. Sehingga motivasi belajar yang di dapat tidak optimal.

\section{METODE PENELITIAN}

Jenis penelitian yang akan digunakan dalam penelitian ini adalah penelitian kausalitas yaitu pengaruh disiplin, motivasi belajar, keterampilan mengajar guru dan media pembelajaran terhadap minat belajar siswa kelas XII SMK Negeri 2 Bukittinggi. Penelitian ini menggunakan metode penelitian kuantitatif yaitu suatu penelitian yang berlandaskan pada filsafat positivisme, digunakan untuk meneliti pada populasi atau sampel pada umumnya dilakukan secara random, pengumpulan data menggunakan instrumen penelitian, analisis data bersifat kuantitati/statistik dengan tujuan untuk menguji hipotesis yang telah ditetapkan (Sugiyono 2017:14).

Sesuai dengan rumusan masalah maka jenis penelitian ini adalah kausalitas. Tempat pelaksanaan penelitian ini di SMK N 2 Bukittinggi beralamatkan Jl. Syech Jamil Jambek, Aua Tajungkang Bukittinggi dan penelitian ini dilaksanakan pada bulan Mei 2021 sampai selesai. Populasi dalam penelitian ini adalah seluruh siswa kelas XII AKL SMK N 2 Bukittinggi.

Pengambilan sampel dalam penelitian ini yaitu dengan metode Stratified Rendom Sampling dengan 62 sampel. Sumber data dalam penelitian ini didapatkan dari Tata Usaha SMK Negeri 2 Bukittinggi, Ketua jurusan AKL, dan Seluruh siswa kelas XII SMK $\mathrm{N} 2$ Bukittinggi. Instrumen yang digunakan dalam pengumpulan data penelitian ini adalah angket yang disusun dari indikator-indikator dan untuk mengukur skor variabel digunakan dalam bentuk Skala Likert yang terdiri dari 5 kategori dengan pernyataan Selalu (SL), Sering (SR), Kadang-Kadang (KD), Jarang (JR), Tidak Pernah (TP). Data yang telah dikumpulkan selanjutnya dianalisis dengan analisis statistik menggunakan Analisis Regresi Linier Berganda. 
HORIZON

PENDIDIKAN
JURNAL HORIZON PENDIDIKAN

Publish by: Library of STKIP PGRI Sumatera Barat

E-ISSN : 2775-5770

Vol. 1 No. 4 (November 2021) (748-756)

http://ejournal.stkip-pgri-sumbar.ac.id/index.php/horizon

\section{HASIL DAN PEMBAHASAN}

Dalam penelitian ini proses pengolahan data yang dilakukan dengan menggunakan bantuan SPSS dan eviews, sesuai dengan analisis data mengunakan pengujian regresi linier. Hasil uji $\mathrm{T}$ penelitian ini adalah :

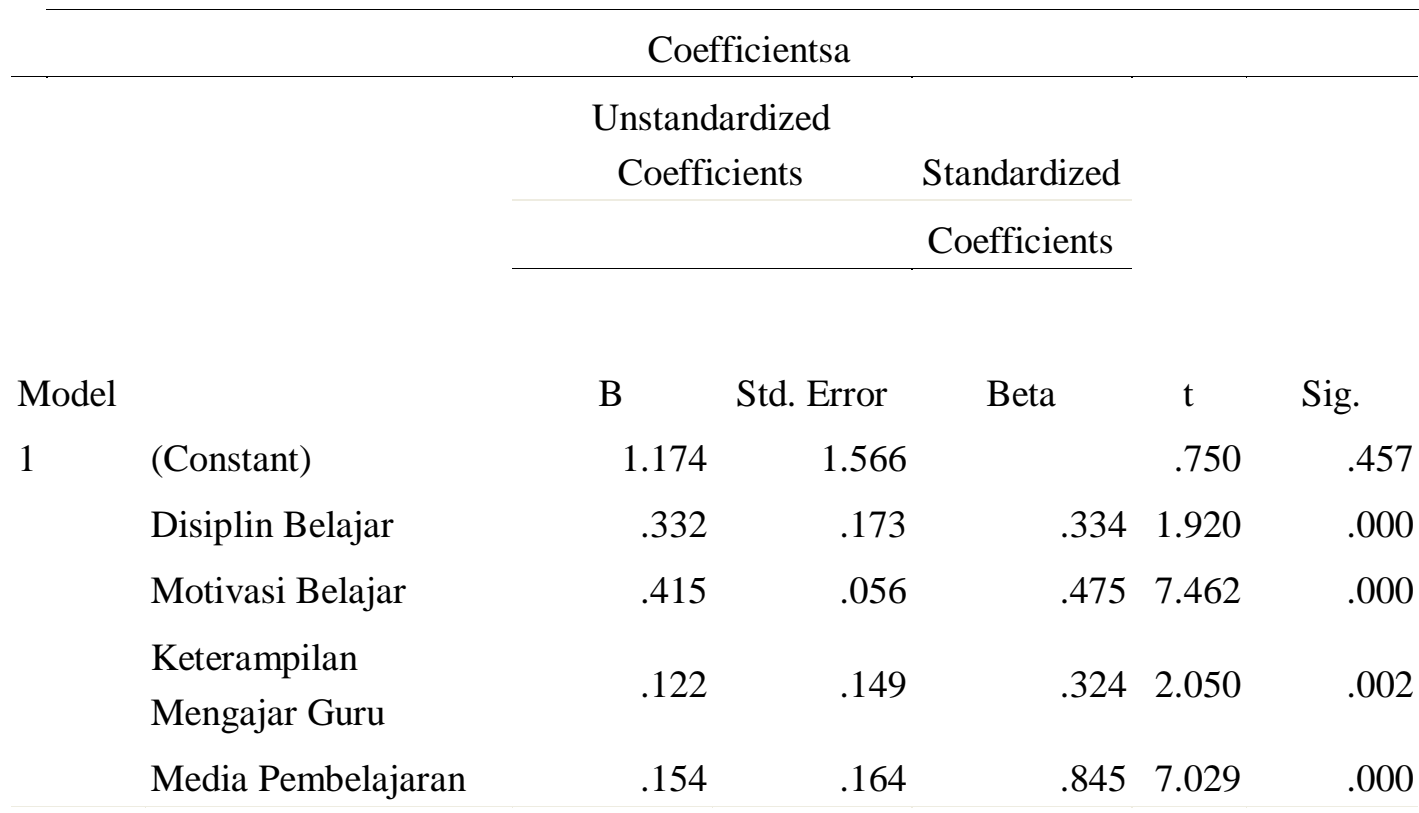

a. Dependent Variable: Minat Belajar

Hasil penelitian analisis sebesar $73,52 \%$ dan termasuk diperoleh TCR variabel disiplin kategori cukup. Hal ini dapat belajar diperoleh rata-rata sebesar dimaknai secara keseluruhan bahwa 3,74 dan TCR $74,47 \%$. Hal ini persepsi siswa tentang motivasi menunjukkan variabel disiplin belajar pada siswa kelas XII AKL di belajar berada pada kategori cukup. SMK Negeri 2 Bukittinggi Dengan demikian dapat dinyatakan bahwa disiplin belajarpada kategori cukup.

Variabel responden untuk variabel persepsi siswa tentang motivasi belajar adalah 3,74 dengan tingkat pencapaian responden dikategorikan cukup.

Variabel persepsi siswa tentang keterampilan mengajar guru adalah 3,46 dengan tingkat pencapaian responden sebesar $69,42 \%$ dan termasuk kategori cukup. Hal ini dapat dimaknai secara 
HORIZON

PENDIDIKAN

JURNAL HORIZON PENDIDIKAN

Publish by: Library of STKIP PGRI Sumatera Barat

E-ISSN : 2775-5770

Vol. 1 No. 4 (November 2021) (748-756)

http://ejournal.stkip-pgri-sumbar.ac.id/index.php/horizon

keseluruhan bahwa persepsi siswa tentang keterampilan mengajar guru pada siswa kelas XII AKL di SMK Negeri 2 Bukittinggi dikategorikan cukup.

Sedangkan variabel persepsi siswa tentang media pembelajaran adalah 3,91 dengan tingkat pencapaian responden sebesar $78,79 \%$ dan termasuk kategori cukup. Hal ini dapat dimaknai secara keseluruhan bahwa persepsi siswa tentang media pembelajaran pada siswa kelas XII AKL di SMK Negeri 2 Bukittinggi dikategorikan cukup.

Disiplin belajar (X1) sangat mempengaruhi minat belajar siswa (Y), pengaruh yang lebih besar itu terdapat pada kelompok sampel akses internet tidak lancar, dibandingkan dari sampel akses internet lancar yang dimiliki siswa,yang ditunjukan dengan nilai koefisien disiplin belajar sebesar 0,268 dan koefisien tersebut signifikan, dengan nilai thitung sebesar 4,588 lebih besar dari pada ttabel sebesar 2,059. Hal ini disebabkan dengan jaringan tidak lancar yang rendah maka siswa akan kesulitan dalam melaksanakan proses pembelajaran jarak jauh sehingga hal ini akan mempengaruhi minat belajar siswa.

Motivasi Belajar (X2) sangat mempengaruhi minat belajar siswa (Y), pengaruh yang lebih besar itu terdapat pada kelompok sampel akses internet tidak lancar, dibandingkan dari sampel akses internet lancar yang dimiliki siswa,yang ditunjukan dengan nilai koefisien motivasi belajar sebesar 0,188 dan koefisien tersebut signifikan, dengan nilai thitung sebesar 6,826 lebih besar dari pada ttabel sebesar 2,059. Hal ini disebabkan dengan jaringan tidak lancar yang rendah maka akses siswa untuk mengakses internet sebagai acuan proses pembelajaran online akan terganggu akan mempengaruhi minat belajar siswa.

Keterampilan Mengajar Guru (X3) sangat mempengaruhi minat belajar siswa (Y), pengaruh yang lebih besar itu terdapat pada kelompok sampel akses internet tidak lancar, dibandingkan dari sampel akses internet lancar yang dimiliki siswa,yang ditunjukan dengan nilai koefisien motivasi belajar sebesar 


\section{HORIZON}

PENDIDIKAN
JURNAL HORIZON PENDIDIKAN

Publish by: Library of STKIP PGRI Sumatera Barat

E-ISSN : 2775-5770

Vol. 1 No. 4 (November 2021) (748-756)

http://ejournal.stkip-pgri-sumbar.ac.id/index.php/horizon
0,131 dan koefisien tersebut signifikan, dengan nilai thitung sebesar 3,009 lebih besar dari pada ttabel sebesar 2,059. Hal ini disebabkan bagaimana proses cara mengajar guru yang berbeda dibandingkan dengan pembelajaran konvesional akan mempengaruhi minat belajar siswa..

Media Pembelajaran (X4) sangat mempengaruhi minat belajar siswa (Y), pengaruh yang lebih besar itu terdapat pada kelompok sampel akses internet tidak lancar, dibandingkan dari sampel akses internet lancar yang dimiliki siswa,yang ditunjukan dengan nilai koefisien motivasi belajar sebesar 1,437 dan koefisien tersebut signifikan, dengan nilai thitung sebesar 6,374 lebih besar dari pada ttabel sebesar 2,059. Hal ini disebabkan media pembelajaran yang disediakan berkaitan dengan kecepatan akses internet yang dimiliki siswa apabila hal tersebut terlalu berat ataupun sulit diakses akan mempengaruhi minat belajar siswa.
Dari hasil pengolahan data menunjukkan bahwa nilai Fhitung 26,453 lebih besar Ftabel 2,53 dan nilai signifikan 0,000 lebih kecil dari 0,05. Hal ini berarti H0 ditolak dan Ha diterima. Dengan demikian dapat dikatakan bahwa disiplin belajar, motivasi belajar, keterampilan mengajar guru dan media pembelajaran berpengaruh terhadap minat belajar siswa kelas XII AKL SMK Negeri 2 Bukittinggi.

Uji F Akses Internet Lancar

Dari hasil pengolahan data dapat dilihat pada tabel di atas menunjukkan bahwa nilai Fhitung 11,591 lebih besar Ftabel 2,71 dan nilai signifikan 0,000 lebih kecil dari 0,05. Hal ini berarti H0 ditolak dan Ha diterima. Dengan demikian dapat dikatakan bahwa disiplin belajar, motivasi belajar, keterampilan mengajar guru dan media pembelajaran berpengaruh terhadap minat belajar siswa kelas XII AKL SMK Negeri 2 Bukittinggi.

Uji F pada penelitian ini : 


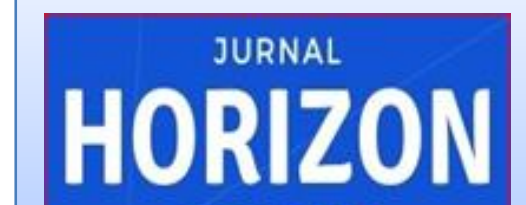

PENDIDIKAN
JURNAL HORIZON PENDIDIKAN

Publish by: Library of STKIP PGRI Sumatera Barat

E-ISSN : 2775-5770

Vol. 1 No. 4 (November 2021) (748-756)

http://ejournal.stkip-pgri-sumbar.ac.id/index.php/horizon

\begin{tabular}{ccccccc}
\hline & & Sum of & & & & \\
& Model & Squares & Df & Mean Square & F & Sig. \\
& Regression & 1550.585 & 4 & 387.646 & 26.453 & $.000^{\mathrm{a}}$ \\
& Residual & 835.286 & 57 & 14.654 & & \\
1 & Total & 2385.871 & 61 & & & \\
\hline
\end{tabular}

Dari hasil pengolahan data dapat

Motivasi Belajar (X2) sangat dilihat pada tabel di atas menunjukkan bahwa nilai Fhitung 20,539 lebih besar Ftabel 2,74 dan nilai signifikan 0,000 lebih kecil dari 0,05. Hal ini berarti H0 ditolak dan Ha diterima. Dengan demikian dapat dikatakan bahwa disiplin belajar, motivasi belajar, keterampilan mengajar guru dan media pembelajaran berpengaruh terhadap minat belajar siswa kelas XII AKL SMK Negeri 2 Bukittinggi.

\section{KESIMPULAN}

Berdasarkan hasil analisis data yang telah dilakukan dapat disimpulkan sebagai berikut :

Disiplin belajar (X1) sangat mempengaruhi minat belajar siswa (Y), pengaruh yang lebih besar itu terdapat pada kelompok sampel akses internet tidak lancar, sehingga hal ini akan mempengaruhi minat belajar siswa. mempengaruhi minat belajar siswa (Y), pengaruh yang lebih besar itu terdapat pada kelompok sampel akses internet tidak lancar, sebagai acuan proses pembelajaran online akan terganggu akan mempengaruhi minat belajar siswa.

Keterampilan Mengajar Guru (X3) sangat mempengaruhi minat belajar siswa (Y), pengaruh yang lebih besar itu terdapat pada kelompok sampel akses internet tidak lancar, dibandingkan dari sampel akses internet lancar yang dimiliki siswa disebabkan bagaimana proses cara mengajar guru yang berbeda dibandingkan dengan pembelajaran konvesional akan mempengaruhi minat belajar siswa.

Media Pembelajaran (X4) sangat mempengaruhi minat belajar siswa (Y), pengaruh yang lebih besar itu terdapat pada kelompok sampel akses internet tidak lancar, Hal ini 
HORIZON

PENDIDIKAN
JURNAL HORIZON PENDIDIKAN

Publish by: Library of STKIP PGRI Sumatera Barat

E-ISSN : 2775-5770

Vol. 1 No. 4 (November 2021) (748-756)

http://ejournal.stkip-pgri-sumbar.ac.id/index.php/horizon disebabkan media pembelajaran yang disediakan berkaitan dengan kecepatan akses internet yang dimiliki siswa apabila hal tersebut terlalu berat ataupun sulit diakses akan mempengaruhi minat belajar siswa.

\section{DAFTAR PUSTAKA}

Alma. (2009a). Pendidik Profesional (Menguasa Metode dan Terampil Mengajar). Alfa Beta.

Ansofino \& dkk. 2016. Buku Ajar Ekonometrika. Padang: Deepublish.

Alma, B. (2009b). Guru Profesional. CV. Alfabeta.

Arikunto, S. (2010). Dasar-dasar Evaluasi Pendidikan. Jakarta: Bumi Aksara. 2010. In Manajemen Penelitian.

Dalyono. (2005). Psikologi Pendidikan. PT. Rineka Cipta.

Depdikbud. (1996). Kamus Besar Bahasa Indonesia. Balai Pustaka.

Djaali. (2007). Psikologi Pendidikan. Bumi Aksara.
P. Siagian, S. (2010). MANAJEMEN SUMBER DAYA MANUSIA. In Jakarta: cetakan kedelapan belas BUMI RAKSA (Vol. 21).
Rusman, D. . 2013. (2013). Pembelajaran Berbasis Tekhnologi Informasi Dan Komunikasi. Rajawali Pers: Depok Berdasarkan, 1, 6-7.

Sardiman. (2011). Interaksi Dan Motivasi Belajar Mengajar. Rajawali Pers.

Surya, M. (2003). Teori-Teori Konseling. Pustaka Bani Quraisy.

Suwarna, Gufron, A., Sofyan, H., Munadi, S., Budiningsih, C. A., Haryanto, Soenarto, S., Sugito, Sujarwo, Mukminan, \& Sukirman. (2013). Modul Pelatihan Pengembangan Keterampilan Dasar Teknik Instruksional (PEKERTI). Keterampilan Dasar Mengajar.

Syahputra, E. (2020). SNOWBALL THROWING TINGKATAN Minat dan Hasil Belajar.

Uno, B. H. (2011). Teori Motivasi dan Pengukurannya. Bumi Aksara. 